\title{
Identifikasi Metode Pengembangan Sistem Informasi di Indonesia: A Systematic Literature Review
}

\author{
Fardiansyah Ibrahim $^{1 *}$, Thami Rusdi Agus ${ }^{2}$, Nariza Wanti Wulan Sari ${ }^{3}$ \\ ${ }^{1,2}$ Universitas AMIKOM \\ ${ }^{3}$ Universitas Mulia
}

*f.ibrahim@students.amikom.ac.id

\begin{abstract}
Information system is a collection of components that support each other and relate to achieve a goal. There are two methods that can be used to develop information systems, namely object-oriented methods and structured methods. In 2020, it is not yet known how many systems or applications have been designed and built or developed by these two methods. This study aims to identify two systems development methods used in the 2020 time frame. Data obtained from Google Scholar using the Publish or Perish application with the keyword "information system design" during the period 2020. This study uses the Systematic Literature Review (SLR) method. to identify, analyze and discuss all the data needed in this research. It was concluded that in 2020 publications regarding the development of information systems were dominated by structured methods, namely 67 publications from 83 publications that had been obtained.
\end{abstract}

Keywords: information systems, information system design, systematic literature review

\begin{abstract}
Abstrak
Sistem informasi merupakan sekumpulan komponen yang saling mendukung dan berhubungan untuk mencapai suatu tujuan. Terdapat dua metode yang dapat digunakan untuk mengembangkan sistem informasi, yaitu metode berorientasi objek dan metode terstruktur. Pada tahun 2020 ini, belum diketahui berapa banyak sistem atau aplikasi yang telah dirancang dan dibangun atau dikembangkan oleh kedua metode tersebut. Penelitian ini bertujuan untuk mengidentifikasi dua metode pengembangan sistem yang digunakan dalam kerangka waktu 2020. Data diperoleh dari Google Scholar dengan menggunakan aplikasi Publish or Perish dengan kata kunci "Perancangan sistem informasi" selama periode tahun 2020. Penelitian ini menggunakan metode Systematic Literature Review (SLR) untuk mengidentifikasi, menganalisis dan membahas semua data yang dibutuhkan dalam penelitian ini. Diperoleh kesimpulan bahwa pada tahun 2020 publikasi mengenai pengembangan sistem informasi di dominasi oleh metode terstruktur, yaitu 67 publikasi dari 83 publikasi yang telah diperoleh.
\end{abstract}

Kata kunci: sistem informasi, perancangan sistem informasi, systematic literature review

\section{Pendahuluan}

Sistem informasi merupakan sekumpulan komponen yang saling membantu dan berhubungan untuk mencapai suatu tujuan [1]. Dewasa ini perkembangan sistem informasi terus berkembang pesat. Dengan adanya sistem informasi, semua pekerjaan yang dilakukan secara manual seperti perekaman dan hardcopy file kini dapat dilakukan dengan komputer [2] [3]. Dengan demikian banyak instansi atau perusahaan yang berusaha membangun sistem informasi yang berguna untuk proses bisnisnya [3].
Pada tahun 2020 telah banyak dipublikasikan hasil riset mengenai pengembangan sistem infomasi dengan objek atau kasus dan metodenya masing-masing. Pada umumnya metode yang digunakan untuk mengembangkan sistem informasi, yaitu metode berorientasi objek dan metode terstruktur. Untuk dapat mengidentifikasi, menganalisis dan mengupas mengenai publikasi dari pada pengembangan sistem informasi ini maka digunakan metode Systematic Literature Review (SLR). Sehingga dengan metode ini dapat diketahui kecenderungan metode pengembangan sistem 
yang digunakan di Indonesia selama tahun 2020.

\section{Metode Penelitian}

Objek dalam penelitian ini adalah publikasi dengan metode perancangan dan pengembangan sistem informasi. Metode Systematic Literature Review (SLR) yang digunakan dalam penelitian ini terdiri dari tiga tahapan yaitu planning, conducting, dan reporting. Berikut penjabaran dari proses atau tahapan dalam SLR.

\section{a. Planning}

Tahap awal dilakukan perencanaan proses pencarian dan ekstraksi publikasi. Pembuatan pertanyaan pada tahap ini berdasarkan lima elemen, yaitu Population, Intervention, Comparison, Outcomes, dan Context atau disebut dengan PICOC.

b. Conducting

Tahap ini merupakan pelaksanaan dari SLR yang telah ditentukan. Proses penyaringan berdasarkan kriteria inclusion yakni,

1. Publikasi jurnal dilakukan pada tahun 2020.

2. Data yang diperoleh berasal dari Google Scholar yang diperoleh melalui aplikasi Publish or Perish.

3. Data yang digunakan berada dalam lingkup sistem informasi.

4. Data memiliki sumber yang jelas dan dipublikasikan dalam jurnal terakreditasi.

5. Data jurnal yang diperoleh telah menjadi acuan untuk penelitian lain minimal satu kali.

Dan kriteria exclusionnya yaitu penelitian yang tidak ditulis dalam bahasa Indonesia.

Dalam penelitian ini, data yang telah terkumpul akan dievaluasi berdasarkan kriteria pertanyaan sebagai berikut:

Q1: Apakah jurnal di terbitkan pada tahun 2020?

Q2: Apakah jurnal yang yang diterbitkan memberikan penjelasan mengenai metode yang digunakan
Dari masing-masing pertanyaan tersebut akan diberikan skor berdasarkan jawaban seperti di bawah ini:

Y (Yes): untuk masalah dan metode yang ditulis dalam jurnal terbitan tahun 2020, dan T (No): untuk yang tidak menuliskan masalah dan metode. Selanjutnnya data yang telah terkumpul akan dianalisis untuk memberikan jawaban sebagai berikut:

1. Metode pengembangan sistem yang digunakan dalam pengembangan sistem informasi (Q1).

2. Kelemahan metode yang digunakan $(\mathrm{Q} 2)$.

c. Reporting

Pada tahap ini adalah penyampaian hasil dalam bentuk tulisan.

\section{Hasil Penelitian}

\subsection{Planning}

Berikut merupakan lima elemen PICOC dalam penelitian ini.

Tabel 1. PICOC

\begin{tabular}{cc}
\hline Populasi & $\begin{array}{c}\text { Sistem informasi, } \\
\text { rancangan sistem } \\
\text { informasi, }\end{array}$ \\
Intervensi & Metode perancangan, \\
Perbandingan & $\begin{array}{c}\text { Metode berorientasi } \\
\text { objek, metode } \\
\text { terstruktur }\end{array}$ \\
Hasil & $\begin{array}{c}\text { Metode perancangan } \\
\text { sistem yang digunakan }\end{array}$ \\
& Penelitian dalam \\
Konteks & industri dan akademik \\
\hline
\end{tabular}

\subsection{Conducting}

Proses pencarian data menggunakan aplikasi publish atau perish dengan mengakses halaman Google Scholar menggunakan kata kunci "Perancangan Sistem Informasi”, selama tahun 2020. Hasil pencarian data awal, ditemukan sejumlah 951 data yang terdiri dari jurnal, prosiding, dan kutipan. 


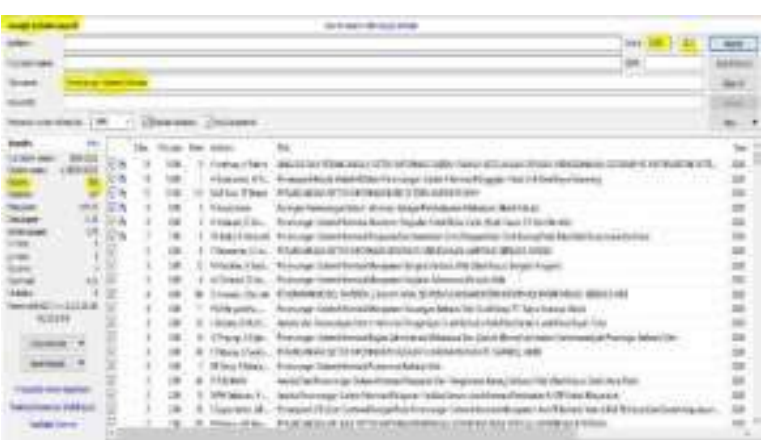

Gambar 1. Proses Pencarian Menggunakan Publish or Perish

Hasil dari proses pencarian di atas dipilih berdasarkan kriteria sebagai berikut:

1. Publikasi jurnal dilakukan pada tahun 2020.

2. Data yang diperoleh berasal dari Google Scholar yang diperoleh melalui aplikasi publish atau perish.

3. Data yang digunakan berada dalam lingkup sistem informasi.

4. Data memiliki sumber yang jelas dan dipublikasikan dalam jurnal terakreditasi.

5. Data jurnal yang diperoleh telah menjadi acuan untuk penelitian lain (kutipan) minimal satu kali.

Hasil seleksi berdasarkan kriteria di atas akhirnya menyisakan 83 jurnal dan selanjutnya diseleksi kembali sesuai penilaian kualitas, adapun 83 jurnal yang digunakan terlampir pada daftar pustaka. Selanjutnya dilakukan evaluasi berdasarkan kriteria jurnal terbit pada tahu 2020 dan memberikan penjelasan metode yang digunakan. Diperoleh 83 jurnal yang digunakan dalam penelitian ini telah lolos quality assessment.

Tahap selanjutnya akan menjawab pertanyaan dari Research Question dan membahas hasil dari metode dan pendekatan yang dominan muncul pada tahun 2020 .

1. Pertanyaan Penelitian 1 (R1). Apa saja metode yang digunakan dalam perancangan, pembangunan dan pengembangan sistem informasi di tahun 2020 ?

83 jurnal dikelompokkan berdasarkan metode pengembangan sistem yang digunakan untuk menjawab Pertanyaan Penelitian (R1) dan dapat ditampilkan pada tabel berikut:
Table 1. Grouping by Method

\begin{tabular}{lll}
\hline No & Method & Result \\
\hline 1 & Metode Terstruktur & 67 \\
2 & Berorientasi Objek & 16 \\
\hline
\end{tabular}

Metode terstruktur meningkatkan kontrol manajemen dengan membagi tugas-tugas kompleks menjadi bagianbagian yang lebih kecil dan lebih mudah dikelola [4]. Tahapan dalam metode terstruktur adalah sebagai berikut:

a. Perencanaan

Tahap ini merupakan tahap untuk mendefinisikan masalah dan menentukan tujuan kegiatan yang melibatkan perkiraan kebutuhan fisik, tenaga kerja, dan keuangan yang diperlukan untuk mendukung pengembangan sistem dan mendukung operasinya setelah implementasi.

b. Analisis

Tahap ini merupakan tahap untuk mengidentifikasi masalah dan mencari solusi. Biasanya dibuat flowchart untuk mengidentifikasi.

c. Rancangan

Tahapan ini merupakan tahapan perancangan sistem dari kegiatan yang dilakukan yaitu membuat pemodelan proses, membuat pemodelan data dalam bentuk DFD (Data Flow Diagram) dan membuat desain antarmuka.

d. Pengembangan

Tahap ini merupakan tahap pembuatan arsitektur teknis dan database. Ubah desain logis menjadi kode menggunakan bahasa pemrograman tertentu.

e. Pengujian

Pada tahap ini tidak hanya menguji desain yang digunakan tetapi menguji semua sistem yang telah ditentukan sebelumnya, seperti tidak ada kesalahan, gambar yang salah, pengujian sistem seperti penyimpanan data, dan lain-lain. 
f. Penerapan

Tahap ini merupakan tahap implementasi sistem baru dan memastikan sistem baru dapat berjalan dengan optimal.

g. Pemeliharaan

Tahap ini merupakan tahap terakhir untuk mengevaluasi kinerja sistem, apakah sudah sesuai dengan keinginan pengguna atau tidak. Pada akhir tahap ini juga dilakukan kontrol dan perbaikan secara berkala.

2. Research Question 2 (R2). Apa kelemahan metode yang digunakan dalam merancang, membangun dan mengembangkan sistem informasi?

Kekurangan dari metode terstruktur adalah:

a. Berorientasi pada proses, sehingga mengabaikan persyaratan nonfungsional.

b. Interaksi antara analisis atau pengguna tidak menyeluruh, karena sistem telah ditetapkan sejak awal sehingga tidak adaptif terhadap perubahan (kebutuhan baru).

c. Selain menggunakan desain logika dan DFD, alat yang digunakan untuk berkomunikasi dengan pengguna juga tidak cukup, sehingga sangat sulit bagi pengguna untuk mengevaluasi.

d. Metode terstruktur sangat sulit untuk memutuskan kapan harus menghentikan dekomposisi dan mulai membangun sistem.

e. Metode terstruktur tidak selalu memenuhi kebutuhan pengguna.

\section{Kesimpulan}

Berdasarkan penelitian ini diperoleh kesimpulan bahwa berdasarkan metode systematic literature review yang dilakukan pada publikasi yang terbit pada tahun 2020, metode yang dominan digunakan di Indonesia adalah metode terstruktur, hal ini dikarenakan metode terstruktur pendekatan yang digunakan adalah visual sehingga memberikan

kemudahan

dalam

pengimplementasiannya.

\section{Saran}

Untuk penelitian selanjutnya disarankan untuk menambahkan kriteria penilaian kualitas untuk meningkatkan akurasi penyaringan publikasi.

\section{Daftar Pustaka}

[1] Krismiaji, Sistem Informasi Akuntansi, Keempat. Yogyakarta: UPP STIM YKPN, 2015.

[2] N. H. Cahyana, B. Yuwono, and A. Y. Asmoro, "PENGEMBANGAN SISTEM INFORMASI PERSEDIAAN BARANG BERBASIS WEB DI PT. PUTERA AGUNG SETIA," Semin. Nas. Inform., vol. 1, no. 4, Jul. 2015.

[3] E. A. Hayat, E. Retnadi, and E. Gunadhi, "Perancang Sistem Informasi Kependudukan Berbasis Web," J. Algoritm., vol. 11, no. 1,

[4] P. Ragunath, S. Velmourougan, P. Davachelvan, S. Kayalvizhi, and $R$. Ravimohan, "Evolving A New Model (SDLC Model-2010) For Software Development Life Cycle (SDLC)," Int. J. Comput. Sci. Netw. Secur., 2010.

[5] I. Jadalowen, "Structured Analysis and Structured Design (SSAD) Summary," Softw. Eng. Res. Netw.

[6] Imtihan, K, \& Fahmi, H (2020). ANALISIS DAN ,PERANCẢNGAN SISTEM INFORMASI DAERAH RAWAN MENGGUNAKAN GEOGRAPHIC INFORMATION SYSTEMS (GIS). ... Informatika dan Sistem Informasi, ejournal.stmiklombok.ac.id, http://ejournal.stmiklombok.ac.id/index.php/misi/art icle/view/128

[7] Kurniawan, H, Apriliah, W, Kurnia, I, \& ... (2020). Penerapan Metode Waterfall Dalam Perancangan Sistem Informasi Penggajian Pada Smk Bina Karya Karawang.

Teknologi Informasi .... alumni.rosma.ac.id, https://alumni.rosma.ac.id/index.php/interko $\mathrm{m} /$ article/view/78

[8] Rais, NAR, \& Efendi, TF (2020) PERANCANGAN SISTEM INFORMASI BATIK DI TOKO ANDINI PLUPUH. ... Seminar Nasional \& Call for Paper .... prosiding.stie-aas.ac.id, http://prosiding.stieaas.ac.id/index.php/prosenas/article/view/57

[9] Vidiasari, A, \& Darwis, D (2020). Perancangan Sistem Informasi Akuntansi Penjualan Kredit Buku Cetak (Studi Kasus: CV Asri Mandiri). Jurnal Madani: Ilmu Pengetahuan .... jurnalmadani.org, http://jurnalmadani.org/index.php/madani/art icle/view/77

[10]Badii, YA, \& Herawati, R (2020). Perancangan Sistem Informasi Penjualan Dan Bembelian Serta Pengendalian Stok Barang Pada Toko Batik Kusumawardani Solo. Go Infotech: Jurnal Ilmiah STMIK AUB, jurnal.stmik-aub.ac.id, http://jurnal.stmikaub.ac.id/index.php/goinfotech/article/view/7 5

[11]Rahmanto, Y, \& Hotijah, S (2020). PERANCANGAN SISTEM INFORMASI GEOGRAFIS KEBUDAYAAN LAMPUNG 
BERBASIS MOBILE. ... Data Mining dan Sistem Informasi, ejurnal.teknokrat.ac.id, https://ejurnal.teknokrat.ac.id/index.php/JD MSI/article/view/805

[12]Audrilia, M, \& Budiman, A (2020). Perancangan Sistem Informasi Manajemen Bengkel Berbasis Web (Studi Kasus: Bengkel Anugrah). Jurnal Madani: Ilmu Pengetahuan ..., jurnalmadani.org, hittp://jurnalmadani.org/index.php/madani/art icle/view/78

[13] Oktasari, AJ, \& Kurniadi, D (2020). Perancangan Sistem Informasi Manajemen Kegiatan Mahasiswa Berbasis Web. VoteTEKNIKA: Jurnal Vocational Teknik hitp.//ejournal unp ac. ejournal.unp.ac.id, http://ejournal.unp.ac.id/index.php/voteknika /article/view/106536

[14] Irnawati, O, \& Darwati, I (2020). PENERAPAN MODEL WATERFALL DALAM ANALISIS PERANCANGAN SISTEM INFORMASI INVENTARISASI BERBASIS WEB. ... (Jurnal Teknologi dan Sistem Informasi ..., jurnal.stmikroyal.ac.id, https://jurnal.stmikroyal.ac.id/index.php/jurte $\mathrm{ksi} /$ article/view/406

[15] Margaretha, HA, \& Nababan, MNK (2020). Perancangan Sistem Informasi Manajemen Keuangan Berbasis Web Studi Kasus PT. Karya Swadaya Abadi. JURNAL SAINS DAN $\quad . .$. ejournal.sisfokomtek.org, http://ejournal.sisfokomtek.org/index.php/sa1 ntek/article/view/34

[16]Rozana, L, \& Musfikar, R (2020). Analisis dan Perancangan Sistem Informasi Pengarsipan Surat Berbasis Web Pada Kantor Lurah Desa Dayah Tuha. ... : Jurnal Pendidikan Teknologi Informasi, jurnal.arraniry.ac.id, https://www.jurnal.arraniry.ac.id/index.php/cyberspace/article/vie $\mathrm{w} / 6933$

[17]Prayogi, IC, Fajaryanto, A, \& Astuti, IP (2020). Perancangan Sistem Informasi Bagian Administrasi Mahasiswa Dan Alumni (Bama) Universitas Muhammadiyah Ponorogo Berbasis Web. Network Engineering ..., nero.trunojoyo.ac.id, https://nero.trunojoyo.ac.id/index.php/nero/ar ticle/view/159

[18] Oktavia, F, Sadikin, A, \& Irawan, B (2020). PERANCANGAN SISTEM INFORMASI PENGGAJIAN KARYAWAN PADA PT. SAWMILL JAMBI. ... Sistem Informasi, ejournal.stikom-db.ac.id,

http://ejournal.stikomdb.ac.id/index.php/jimsi/article/view/775

[19]Dewi, BR, Rahajo, S, \& Adhitya, E (2020). Perancangan Sistem Informasi Puskesmas Berbasis Web. IKRA-ITH INFORMATIKA ..., journals.upi-yai.ac.id, http://journals.upiyai.ac.id/index.php/ikraith-

informatika/article/download/610/456

[20] Setiawan, MPH, \& Masya, F (2020). Analisa Perancangan Sistem Informasi Pelaporan Fasilitas Umum dan Informasi Pembuatan EKTP Untuk Masyarakat. ... Teknologi dan Sistem Informasi ..., jurnal.univrab.ac.id, http://jurnal.univrab.ac.id/index.php/rabit/arti cle/view/810

[21] Supardianto, S, \& Tampubolon, AB (2020). Penerapan UCD (User Centered Design) Pada Perancangan Sistem Informasi Manajemen Aset TI Berbasis Web di Bid TIK Kepolisian Daerah Kepulauan Riau. Journal of Applied ..., jurnal.polibatam.ac.id https://jurnal.polibatam.ac.id/1ndex.php/JAIC /article/view/2108

[22] Putra, PH, \& Novelan, MS (2020). PERANCANGAN APLIKASI SISTEM
PADA SEKOLAH MENENGAH KEJURUAN. Jurnal Teknovasi: Jurnal Teknik dan Inovasi, core.ac.uk, https://core.ac.uk/download/pdf/322500978. pdf

[23] Ramdan, DS, \& Putra, SAB (2020). Perancangan Dan Implementasi Aplikasi Sistem Informasi Pengelolaan Data UKM (Unit Kegiatan Mahasiswa) Berbasis Web Di Politeknik TEDC Bandung. Jurnal TEDC, ejournal.poltektedc.ac.id,

http://ejournal.poltektedc.ac.id/index.php/ted c/article/view/355

[24] Pratiwi, YA, Ginting, RU, \& ... (2020). Perancangan Sistem Informasi Akademik Berbasis Web Di SMP Rahmat Islamiyah. ... DAN ILMU SOSIAL ..., e-journal.sarimutiara.ac.id, http://e-journal.sarimutiara.ac.id/index.php/tekesnos/article/view 11149

[25] Nurelasari, E (2020). Perancangan Sistem Informasi Akademik Pada Sekolah Menengah Pertama Berbasis Web. Komputika: Jurnal Sistem Komputer, ojs.unikom.ac.id, https://ojs.unikom.ac.id/index.php/komputika /article/view/2243

[26] Sallaby, AF, \& Kanedi, I (2020). Perancangan Sistem Informasi Jadwal Dokter Menggunakan Framework Codeigniter. JURNAL MEDIA INFOTAMA, jurnal.unived.ac.id,

https://jurnal.unived.ac.id/index.php/jmi/artic le/view/1121

[27]Ahmad, A, \& Maulana, R (2020) PERANCANGAN SISTEM INFORMASI MANAJEMEN ASET PADA PT. ACEHLINK MEDIA BERBASIS ANDROID. Jurnal Informatic, Education and ..., jurnal.stmikiba.ac.id, https://jurnal.stmikiba.ac.id/index.php/jiem/a rticle/view/21

[28] Astriyani, E, Sari, MM, \& Herman, H (2020). Perancangan Sistem Informasi Pembayaran Spp Berbasis Web Menggunakan Notifikasi SMS Gateway (Studi Kasus: SMP Puspita Tangerang). Journal Cerita, neliti.com, https://www.neliti.com/publications/299530/ perancangan-sistem-informasi-pembayaranspp-berbasis-web-menggunakan-notifikasi

[29] Yulianto, A, \& Ariani, A (2020). Perancangan Sistem Informasi Pembuatan E-Invoice Pada PT. Hasta Perkasa Graha Berbasis Web. REMIK (Riset dan E-Jurnal Manajemen ..., polgan.ac.id,

http://www.polgan.ac.id/jurnal/index.php/re mik/article/view/10555

[30] Pebrianto, A, Abdillah, R, \& ... (2020). Perancangan Sistem Informasi Penjualan Donat pada PT King Alianz Donuts. Jurnal Riset dan Aplikasi ..., jim.unindra.ac.id, http://jim.unindra.ac.id/index.php/jrami/articl e/view/324

[31] Yanuardi, Y, \& Destriana, R (2020). Perancangan Sistem Informasi Penjualan Online Gas dalam Strategi E-business Menggunakan Analisis Swot. JIKA (Jurnal Informatika), jurnal.umt.ac.id, http://jurnal.umt.ac.id/index.php/jika/article/ view/2451

[32] Ananditya, A, Sriyono, S, \& Yanti, S (2020). Perancangan Sistem Informasi Penjualan Voucher Game Online Berbasis Desktop pada Aren. Net di Depok. Jurnal Riset dạn Aplikasi ..., http://jim.unindra.ac.id/index.php/jrami/articl e/view/210

[33] Rasyidan, M, \& Zaenuddin, Z (2020). PERANCANGAN SISTEM INFORMASI PERSEDIAAN BARANG MENGGUNAKAN METODE AVERAGE 
(STUDI KASUS TOKO NAZAR BANJARMASIN). Technologia: Jurnal Ilmiah, https://ojs.uniskaojs.uniska-bjm.ac.id,

bjm.ac.id/index.php/JIT/article/view/3638

[34] Saputri, G (2020). PERANCANGAN SISTEM INFORMASI RINCIAN BIAYA PRODUK BERBASIS WEB PADA PT ABC. ESIT, jurnal-eresha.ac.id, http://www.jurnal-

eresha.ac.id/index.php/esit/article/view/168

[35]Rahman, HA, \& Saputra, A (2020). Perancangan Sistem Persediaan Barang Berbasis Java untuk Sistem Informasi Showroom dan Bengkel. Jurnal Riset Dan Aplikasi Mahasiswa ..., jim.unindra.ac.id, http://jim.unindra.ac.id/index.php/jrami/articl e/view/348

[36] Ong, D (2020). Analisa Dan Perancangan Sistem Informasi Pemesanan Menu Makanan Dan Minuman Pada Restoran Menggunakan Codeigniter. Respati, jti.respati.ac.id, http://jti.respati.ac.id/index.php/jurnaljti/artic le/view/360

[37]Lusti, H, \& Masya, F Analisa Perancangan Sistem Informasi Pemesanan Pada Wedding Organizer Berbasis Web. CESS (Journal of Computer Engineering, System ... jurnal.unimed.ac.1d,

https://jurnal.unimed.ac.id/2012/index.php/ce ss/article/view/15610

[38] Wijoyo, AC, \& Hermanto, D (2020). Analisis dan Perancangan Sistem Informasi Inventory pada PT Insan Data Permata. Jurnal Riset Dan Aplikasi Mahasiswa ..., jim.unindra.ac.id http://jim.unindra.ac.id/index.php/jrami/articl e/view/231

[39] Sufadmi, H, \& Effiyaldi, E (2020). Analisis Dan Perancangan Sistem Informas Kepegawaian Berbasis Web Pada Kantor Komisi Pemilihan Umum Kota Jambi. Jurnal Manajemen Sistem Informasi, ejournal.stikom-db.ac.id

http://ejournal.stikom-

db.ac.id/index.php/manajemensisteminforma si/article/view/905

[40] Saputra, FI, \& Siahaan, K (2020). Analisis dan Perancangan Sistem Informasi Manajemen Penelitian Dan Pengabdian Kepada Masyarakat Pada (LPPM) Universitas Jambi. Jurnal Manajemen Sistem Informasi, http://ejournal.stikom-

db.ac.id/index.php/manajemensisteminforma si/article/download/865/647

[41]Lestari, DI, Mardiani, R, \& Siregar, IW (2020). Analisis Perancangan dan Implementasi Sistem Informasi Tugas Akhir Berbasis Web untuk Mendukung Keunggulan Bersaing. Prosiding Seminar Hasil ..., journal.unjani.ac.id,

http://journal.unjani.ac.id/index.php/unex/arti cle/view/27

[42]Masayu, E (2020). Analisis Perancangan Sistem Informasi Manajemen Aset PT. Multi Traktor Utama Berbasis Java. Budi Luhur Information journal.budiluhur.ac.id, http://journal.budiluhur.ac.id/index.php/bit/ar ticle/view/922

[43] Subianto, S (2020). Penerapan Metode Rapid Application Development dalam Perancangan Sistem Informasi Pendataan. INFOKAM, amikjtc.com, http://amikjtc.com/jurnal/index.php/jurnal/art icle/view/218

[44] Badrul, M, \& Dewi, NHS (2020). Penerapan Metode Rapid Application Development untuk Perancangan Sistem Informasi Penagihan Piutang Premi Asuransi. J-SAKTI
(Jurnal Sains Komputer dan tunasbangsa.ac.id,

http://tunasbangsa.ac.id/ejurnal/index.php/jsa kti/article/view/223

[45] Nurmalasari, N, \& Rohayani, Y (2020). Penerapan Metode Waterfall Dalam Perancangan Sistem Informasi Akuntansi Pengiriman Barang. JUSTIAN-Jurnal Sistem Informasi https://ejournal.bsi.ac.id/ejurnal/index.php/ju stian/article/view/8058

[46] Yaqin, MA, Sa'adah, A, Puspithasari, NN, \& ... (2020). Perancangan Arsitektur Sistem Informasi Pondok Pesantren Dengan The Open Group Architecture Framework (Togaf). ... Riset Sistem Informasi ..., tunasbangsa.ac.id,

https://tunasbangsa.ac.id/ejurnal/index.php/ju rasik/article/view/168

[47] Jenih, J, Ointu, MAA, \& Sugiarso, T (2020). Perancangan dan Implementasi Sistem Informasi Lokasi Dojang Taekwondo Berbasis Web. Jurnal Teknologi Informasi, ejournal.urindo.ac.id,

http://ejournal.urindo.ac.id/index.php/TI/artic le/view/868

[48] Uddin, B, Suryadi, D, \& Maesaroh, S (2020). Perancangan dan Implementasi Sistem Informasi Penjualan pada CV. Cihanjuang Inti Teknik. Jurnal Teknologi Terpadu, journal.nurulfikri.ac.id,

https://journal.nurulfikri.ac.id/index.php/jtt/a rticle/view/256

[49] Lestari, RH, Sumitra, A, Nurunnisa, R, \& ... (2020). Perancangan Perencanaan Pembelajaran Anak Usia Dini Melalui Sistem Informasi Berbasis Website. Jurnal Obsesi: Jurnal ..., obsesi.or.id, https://www.obsesi.or.id/index.php/obsesi/art icle/view/770

[50] Rizqya, N (2020). Perancangan Sistem Informasi Akuntansi Laporan Posisi Keuangan Pada UMKM Berbasis WEB (Studi Kasus UMKM Home Catering). Jurnal Ilmiah KOMPUTASI, ejournal.jak-stik.ac.id, https://ejournal.jak-

stik.ac.id/index.php/komputasi/article/view/6 5

[51] Widiastutik, V, Probowulan, D, \& ... (2020). Perancangan Sistem Informasi Akuntansi Penggajian (Manual). BUDGETING: Journal of .... journal.ipm2kpe.or.id, https://journal.ipm2kpe.or.id/index.php/BUD' GETING/article/view/1758

[52] Kusumaratri, RD (2020). PERANCANGAN SISTEM INFORMASI AKUNTANSI PIUTANG PADA CV MENANG SENTOSA. SISTEMASI: Jurnal Sistem Informasi, sistemasi.ftik.unisi.ac.id, http://sistemasi.ftik.unisi.ac.id/index.php/stm si/article/view/712

[53] Alfiansyah, D, \& Supriyati, S (2020): Perancangan Sistem Informasi Akuntansi Piutang Usaha Pada Bapel JPKM Surya Sumirat Menggunakan PHP MySQL. @ is The Best: Accounting search.unikom.ac.id,

https://search.unikom.ac.id/index.php/aistheb est/article/view/3239

[54]Annas, F (2020). Perancangan Sistem Informasi Bank Soal Online Di SMP Negeri 3 Matur. Jurnal Educative: Journal of Educational ejournal.iainbukittinggi.ac.id, hittp://ejournal.iainbukittinggi.ac.id/index.php /educative/article/view/2522

[55] Sari, SM, Abidin, DZ, \& Devitra, J (2020). Perancangan Sistem Informasi Berbasis WEB Pada Wedding Organizer Kurnia Jambi. Jurnal Ilmiah Mahasiswa ..., ejournal.stikom- 
db.ac.id

http://ejournal.stikomdb.ac.id/index.php/jimti/article/view/807

[56] Tiara, E, Sika, X, \& Devitra, J (2020). Perancangan Sistem Informasi E-commerce Pada Butik Rumah Warna Jambi. ... Mahasiswa Sistem Informasi, ejournal.stikom-db.ac.id

http://ejournal.stikom-

db.ac.id/index.php/jimsi/article/view/780

[57]Purwanto, A, Hanief, S, \& Nugroho, A (2020). Perancangan sistem informasi eksekutif berbasis web pada upt laboratorium hayati pertanian bali untuk penentuan penyakit pada bibit tanaman. no. February, researchgate.net,

https://www.researchgate.net/profile/Ir Mko $\mathrm{m} /$ publication/338987716 PERANCANGA $\mathrm{N}$ SISTEM INFORMAST EKSEKUTIF B ER $\bar{B} A S I S$ WEB PADA UPT LABORAT ORIUM HAYATI PERTANIĀN BALI U NTUK PENENTUAN PENYAKTT PADA BIBIT_TANAMAN/links/5e371afaä6fdccd 96581aaeb/PERANCANGAN-SISTEMINFORMASI-EKSEKUTIF-BERBASISWEB-PADA-UPT-LABORATORIUMHAYATI-PERTANIAN-BALI-UNTUKPENENTUAN-PENYAKIT-PADA-BIBITTANAMAN.pdf

[58]Firman, F, Muzita, F, \& ... (2020) Perancangan Sistem Informasi Evaluasi Prestasi Belajar Siswa Berbasis Web di SMK Negeri 3 Makassar. ... Teknologi Informasi), unimuda.e-journal.id, https://unimuda.ejournal.id/jurnalteknologiinformasi/article/vi ew/482

[59]Ardiyanto, M (2020). Perancangan Sistem Informasi Haji Dan Umroh Pada Otto Pariwisata Ardana Tour. ... Ristek (Seminar Nasional Riset dan Inovasi ... proceeding.unindra.ac.id,

http://www.proceeding.unindra.ac.id/index.p hp/semnasristek/article/view/1120

[60]Midi, A (2020). PERANCANGAN SISTEM INFORMASI KEUANGAN BOUTIQUE. Jurnal Teknologi Dan Sistem Informasi Bisnis, $\quad$ jurnal.unidha.ac.id, http://www.jurnal.unidha.ac.id/index.php/jte ksis/article/view/86

[61] Kurniawan, BD, Andryana, S, \& ... (2020). Perancangan Sistem Informasi Laporan Asset Berbasis Smartphone dengan Metode Waterfall. JURNAL MEDIA ..., ejurnal.stmik-budidarma.ac.id,

https://www.ejurnal.stmik-

budidarma.ac.1d/index.php/mib/article/view/ 2220

[62] Sitompul, DS, Amroni, A, \& ... (2020). PERANCANGAN SISTEM INFORMASI LAYANAN DAN PENDAFTARAN UMAT PADA GEREJA HKBP HITAMULU BANGKO BERBASIS WEB. ... Sistem Informasi, ejournal.stikom-db.ac.id, http://ejournal.stikomdb.ac.id/index.php/jimsi/article/view/777

[63] Manurung, RAY, \& Manuputty, AD (2020). Perancangan Sistem Informasi Lembaga Kemahasiswaan Universitas Kristen Satya Wacana Salatiga. Jurnal SITECH: Sistem Informasi ..., jurnal.umk.ac.id, https://jurnal.umk.ac.id/index.php/sitech/artic le/view/4703

[64] Stevany, R, Hidayat, T, \& Agustine, D (2020). Perancangan Sistem Informasi Management Inventory Pada PT. Adiperkasa Anugrah Pratama Berbasis Web. Jutis (Jurnal Teknik ..., ejournal.unis.ac.id http://ejournal.unis.ac.id/index.php/jutis/artic le/view/136

[65] Kusumah, RA, Witanti, W, \& ... (2020). Perancangan Sistem Informasi Manajemen
Aset Tetap Pada PT Perkebunan Nusantara VIII. ... Teknologi Komputer \& ..., seminarid.com, hittp://seminarid.com/prosiding/index.php/sainteks/article/v iew/424

[66]Manu, G, \& Tugil, H (2020). PERANCANGAN SISTEM INFORMASI MANAJEMEN EKSTRAKURIKULER (SIME) BERBASIS WEB. Jurnal Pendidikan Teknologi Informasi (JUKANTI), cbn.ac.id, https://cbn.ac.id/ojs3/index.php/jukanti/articl e/view/91

[67] Jafar, R, Abdullah, MH, \& Safi, M (2020). Perancangan Sistem Informasi Menejemen Sarana Dan Prasarana Menggunakan Framework Codeigniter Pada Akademi Ilmu Komputer Ternate. Jurnal Ilmiah ILKOMINFO-Ilmu ..., j-ilkominfo.org, http://j-

ilkominfo.org/index.php/ejournalaikom/articl e/view/103

[68] Iskandar, R, \& Akhiyar, D (2020). Perancangan Sistem Informasi Pelayanan Klinik ATidza Kota Padang Berbasis Web. MAJALAH ILMIAH, lppm.upiyptk.ac.id, http://lppm.upiyptk.ac.id/ojsupi/index.php/M AJALAHILMIAH/article/view/1654

[69] Sutoyo, I (2020). Perancangan Sistem Informasi Pembayaran SPP Terpadu Menggunakan Model Prototipe. INTI Nusa Mandiri, ejournal.nusamandiri.ac.id, http://ejournal.nusamandiri.ac.id/index.php/i nti/article/view/1125

[70] Utomo, MR, Witama, MN, \& ... (2020). Perancangan Sistem Informasi Pendaftaran Siswa Baru Berbasis Java Dekstop Pada Madrasah Ibtidaiyah Al-Ihsan. ... dan Teknologi Informasi ..., ojs.serambimekkah.ac.id,

http://www.ojs.serambimekkah.ac.id/jnkti/art icle/view/2518

[71] Supriyadi, S, \& Lutfiyana, N (2020). Perancangan Sistem Informasi Pendaftaran Siswa Baru pada SMA Pusaka 1 Jakarta Berbasis Web. Jurnal Informatika ..., publikasiilmiah.unwahas.ac.id,

https://www.publikasiilmiah.unwahas.ac.id/i ndex.php/JINRPL/article/view/3224

[72] Purwati, N, \& Anggreani, N (2020). Perancangan Sistem Informasi Penerimaan Jasa Servis Pada CV. Java Multimedia Yogyakarta. Indonesian Journal on Software ..., ejournal.bsi.ac.id, https://ejournal.bsi.ac.id/ejurnal/index.php/ijs e/article/view/8042

[73] Putra, EK, Witanti, W, Saputri, IV \& (2020). PERANCANGAN SISTEM INFORMASI PENGARSIPAN SURAT BERBASIS WEB DI KECAMATAN XYZ. .... : Jurnal Komputer dan ..., journals.upiyai.ac.id yai.ac.id/index.php/ikraithinformatika/article/download/626/470

[74] Ayu, F, \& Manalu, L (2020). Perancangan Sistem Informasi Pengolahan Data Pelatihan Pada Balai Latihan Masyarakat Pekanbaru Berbasis Web. Jurnal Intra Tech, journal.amikmahaputra.ac.id,

https://www.journal.amikmahaputra.ac.id/ind ex.php/JIT/article/view/68

[75] Winarti, W, Ihsan, M, \& Wulandari, N (2020). Perancangan Sistem Informasi Penjualan Berbasis Web pada Toko Campus Mart Unimuda Sorong dengan PHP Dan MySql. ... Teknologi Informasi), unimuda.ejournal.id, . https://unimuda.ejournal.id/jurnalteknologiinformasi/article/vi ew/390

[76] Simamora, HIT (2020). PERANCANGAN SISTEM INFORMASI PENJUALAN CV 
MITRA TANI MENGGUNAKAN

METODE PROTOTYPE. ... (Jurnal Teknologi dan Sistem Informasi), jurnal.stmikroyal.ac.id

https://jurnal.stmikroyal.ac.id/index.php/jurte $\mathrm{ksi} /$ article/view/552

[77] Suwarti, C (2020). PERANCANGAN SISTEM INFORMASI PENYELEKSIAN BEASISWA PRESTASI KOTA PEKANBARU PADA KANTOR GUBERNUR PROVINSI RIAU BERBASIS WEB. Jurnal Intra Tech, journal.amikmahaputra.ac.id https://www.journal.amikmahaputra.ac.id/ind ex.php/JIT/article/view/66

[78] Kurniawan, A, Abadi, LP, \& Wilson, A (2020). Perancangan Sistem Informasi Penyewaan Bus Pariwisata di Rizky Jaya Transport Berbasis Java. Jurnal Riset dan Aplikasi ..., jim.unindra.ac.id, http://jim.unindra.ac.id/index.php/jrami/articl e/view/240

[79]Rusdianto, D, \& Nurdesni, A (2020) PERANCANGAN SISTEM INFORMASI PERSEDIAAN OBAT BERBASIS WEB PADA APOTEK ANDIR FARMA. J-SIKA Jurnal Sistem Informasi ... ejournal.unibba.ac.id,

http://ejournal.unibba.ac.id/index.php/jsika/article/view/279

[80]Hardiansyah, H, \& Farizy, S (2020). PERANCANGAN SISTEM INFORMASI PERSEDIAN BARANG DENGAN MENGGUNAKAN PYTHON 3.6. 3 DAN MY SQL UNTUK UMKM. jik-Jurnal Ilmu Komputer

[81]Nugraha, AK, \& Pulansari, F (2020). PERANCANGAN SISTEM INFORMASI PERSEWAAN ALAT BERAT BERBASIS WEBSITE MENINGKATKAN PELAYANAN KONSUMEN PADA CV .... JUMINTEN, juminten.upnjatim.ac.id,

http://juminten.upnjatim.ac.id/index.php/jum inten/article/view/50

[82] Andry, JF (2020). Perancangan Sistem Informasi Projek Manajemen Menggunakan Metode Extreme Programming Berbasis Desktop (Studi Kasus: Perusahaan Kontraktor). ... (Jurnal Sistem Informasi dan Manajemen Basis ..., jurnal.darmajaya.ac.id, https://jurnal.darmajaya.ac.id/index.php/SIM ADA/article/view/1651

[83] Listia, BA, Purnama, I, \& Harahap, SZ (2020). PERANCANGAN SISTEM INFORMASI SENSUS PENDUDUK BERBASIS ANDROID PADA DESA MERANTI. Journal of Computer Science ..., jurnal.ulb.ac.id, http://jurnal.ulb.ac.id/index.php/JCoInS/articl e/view/1842

[84] Gamalama, RI, \& Rahmawati, R (2020). Perancangan Sistem Informasi Simpan Pinjam Anggota Koperasi Pada Koperasi Sejahtera. ... Seminar Nasional Riset ..., proceeding.unindra.ac.id, http://proceeding.unindra.ac.id/index.php/se mnasristek/article/view/3675

[85] Agustina, M, Rismawati, N, \& Acep, A (2020). Perancangan Sistem Informasi Simpan Pinjam di Koperasi Karyawan Indomobil MT Haryono. Jurnal Riset Dan Aplikasi ..., jim.unindra.ac.id http://jim.unindra.ac.id/index.php/jrami/articl e/view/257

[86]Sukadi, S, \& Rendrarini, D (2020). Perancangan Sistem Informasi Stok Barang Terpadu pada Toko Handphone di Pasar Singosaren Surakarta. JURNAL PILAR TERNOLOGI ..., pilar.unmermadiun.ac.id, http://pilar.unmermadiun.ac.id/index.php/pila rteknologi/article/view/48

[87] Kustian, N, \& Parulian, D (2020). Perancangan Sistem Informasi Studio Foto Pada Click Five Studio Depok. SINASIS (Seminar Nasional

proceeding.unindra.ac.id,

http://www.proceeding.unindra.ac.id/index.p hp/sinasis/article/view/3977

[88] Fathoni, AK, Cahyadi, D, \& Husain, MS (2020). Perancangan Sistem Tanda dan Informasi Museum/Istana Langkanae Kota Palopo. Skripsi Prodi Pendidikan Seni Rupa hittps://core.ac.uk/download/pdf/304373958. pdf

[89] E. A. Hayat, E. Retnadi, and E. Gunadhi, "Perancang Sistem Informasi Kependudukan Berbasis Web," J. Algoritm., vol. 11, no. 1, 2014. 